\title{
The Effects of a Microorganisms-Based Commercial Product on the Morphological, Biochemical and Yield of Tomato Plants under Two Different Water Regimes
}

\author{
Carmen-Simona Inculet ${ }^{1}$, Gabriela Mihalache ${ }^{1,2, *}$, Vincenzo Michele Sellitto ${ }^{3}$, \\ Raluca-Maria Hlihor ${ }^{1}$ (D) and Vasile Stoleru ${ }^{1, *(D)}$ \\ 1 “Ion Ionescu de la Brad" University of Agricultural Sciences and Veterinary Medicine, 3 M. Sadoveanu, \\ 700440 Iasi, Romania; simona_inculet@yahoo.com (C.-S.I.); rallu_ca@yahoo.com (R.-M.H.) \\ 2 Integrated Center of Environmental Science Studies in the North East Region (CERNESIM), The "Alexandru \\ Ioan Cuza" University of Iasi, 700506 Iasi, Romania \\ 3 MsBiotech SPA, Department of Microbiology, Via Zara 23, 00198 Roma, Italy; \\ michele.sellitto@msbiotechspa.com \\ * Correspondence: gabriela.mihalache.gm@gmail.com (G.M.); vstoleru@uaiasi.ro (V.S.)
}

Received: 22 October 2019; Accepted: 14 December 2019; Published: 16 December 2019

\begin{abstract}
The practice of organic agriculture represents an essential requirement for conserving natural resources and for providing the food necessary for a growing population, on a sustainable basis. Tomatoes are considered to be one of the most important crops worldwide. In this context, the organic production of tomatoes should be taken into more consideration. The use of microorganisms-based commercial products is an alternative to chemical fertilizers. Anyway, the results of their use are still variable because of various factors. The aim of this study was to test the effect of inoculation with AMF, PGPR and fungi-based products (Rizotech plus ${ }^{\circledR}$ ) on the morphological (length of the plants), biochemical (lycopen, polyphenols, antioxidant activity), and number of fruits and yields of four tomato cultivars (Siriana F1, HTP F1, Minaret F1, Inima de Bou) in two different water regimes used for irrigation $\left(200 \mathrm{~m}^{3}\right.$ or $300 \mathrm{~m}^{3}$ of water/hectare) under a protected area. The results showed that the efficiency of Rizotech plus ${ }^{\circledR}$ application is dependent on the cultivar and the amount of water used. Also, it was clearly demonstrated that the microorganism inoculation significantly increased the yield of Minaret F1, Siriana F1 and HTP F1 cultivars as compared to the uninoculated plants, regardless of the water amount used in the experiment. Moreover, it was observed that for the irrigation of all four cultivars, inoculated with Rizotech plus ${ }^{\circledR}$, a lower amount of water $\left(200 \mathrm{~m}^{3} \cdot \mathrm{ha}^{-1}\right)$ can be used to get the same length of plants, number of fruits and yield as in the case of a higher amount of water $\left(300 \mathrm{~m}^{3} \cdot \mathrm{ha}^{-1}\right)$. In the case of lycopene, polyphenols and antioxidant activity, the results varied with the cultivar and the water amount used. This study gives new information about the functionality and performance of the microorganisms from Rizotech plus ${ }^{\circledR}$ product when applied to different tomato cultivars grown in a tunnel, in the condition of two different water regimes, contributing to a better characterization of it and maybe to a more efficient use in agriculture to achieve optimum results.
\end{abstract}

Keywords: organic agriculture; tomato; PGPR; AMF; fungi; irrigation

\section{Introduction}

The decrease of organic crops productivity is directly influenced by the action of biotic and abiotic stress factors. Biotic factors include stresses caused by pathogenic organisms and pests, such as fungi, nematodes, viruses, and insects. Abiotic factors refer to drought, salinity, heavy metals or floods. Yield losses caused by different categories of stress factors can reach up to $50 \%-82 \%[1,2]$. Worldwide, the organic production of tomato is based on the use of organic nutrients, on antimicrobial 
compounds obtained from bacteria or plants for combating pests, on the optimal use of water resources for irrigation, and also on the beneficial effects of soil microorganisms [3,4].

Microorganisms such as arbuscular mychorrhizal fungi (AMF), plant growth-promoting rhizobacteria (PGPR) or fungi play a crucial role in stimulating the growth and development of plants via a myriad of direct or indirect mechanisms such as enhanced nutrient acquisition, phytohormones production, induction of systemic resistance in plants, or competing with harmful soil microorganisms. The use of microorganisms in agriculture as biofertilizers represents an eco-friendly alternative to the chemical products that are excessively used in order to obtain high yields, which is also a new approach to the practice of organic farming [5-7]. According to FiBL reports, farmers are more and more oriented to organic agriculture. If in 2016, 57.8 million hectares were under organic agricultural management, in 2019, 69.8 million hectares of agricultural land will be managed organically [8]. Tomatoes (Lycopersicon esculentum Mill.) are considered very important crops due to their high economic and nutritional values, being a promising crop for organic agriculture. From an economic point of view, the efficiency of tomato culture is ensured by high yields that can exceed $1000 \mathrm{t} / \mathrm{ha}$ /year and by technologies that can easily adapt to field, tunnel or greenhouse cultivation, and soil or hydroponic systems. Regarding nutritional values, tomato fruits contain a high variety of nutrients such as carbohydrates (3\%); proteins $(1.2 \%)$; lipids (1\%); minerals (calcium, magnesium, phosphorus, potassium, sodium, zinc, manganese); vitamins (vitamins $\mathrm{A}$ and $\mathrm{C}$, thiamin, riboflavin, niacin, pantothenic acid and pyridoxine); phenolic acids; flavonoids; and carotenoids, which are also seen as an anticancer agent [9]. Tomato is also a crop known to harbor several microorganisms with root colonizing ability, which, on the one hand, influence directly or indirectly the soil's health through their beneficial activities and on the other hand, promote the growth and development of plants through their PGPR traits [10]. Therefore, it can be considered suitable for cultivation in organic systems. The beneficial effects of AMF, PGPR or fungi have already been demonstrated in many experiments with species of agronomic interest such as common bean, maize, cucumber or tomato [11]. Also, on the market, different products based on AMF, PGPR or fungi can be found. Over the years, researchers and farmers have complained about their efficiency on the plants because of the variability and inconsistency of field results. Factors such as physical and chemical conditions of the soil, poor ability of the microorganisms to colonize the plant roots, temperature, irrigation, as well as host cultivars have been attributed to the variable responses [12]. Therefore, the emerging commercial products need to be tested under different conditions such as water availability or cultivar variety to have a broader view of its functionality and performance in the organic production of crops such as tomatoes.

In this context, the aim of this study was to test the effects of the inoculation with AMF, PGPR and fungi-based products on the morphological, biochemical, number of fruits, and yield of four tomato varieties under two different water regimes used for irrigation $\left(200 \mathrm{~m}^{3}\right.$ or $300 \mathrm{~m}^{3}$ of water/hectare).

\section{Materials and Methods}

\subsection{Plant Material}

Four cultivars of Lycopersicon esculentum (Siriana F1, Minaret F1, HTP F1, and Inima de Bou) were used in experiments. Three of the cultivars (Siriana F1, HTP F1 and Inima de Bou) have indeterminate growth, while Minaret F1 cultivar has semi-determinate growth. Siriana F1 is an early growing cultivar, known to produce its first fruits after $\sim 100$ days. The fruits are red, spherical and slightly flattened, with a medium weight of $140 \mathrm{~g} /$ fruit. One plant can produce 5-5.5 kg of fruits. Minaret F1, as Siriana F1, is a fast growing cultivar, with dark red, firm fruits that can weight $180-200 \mathrm{~g} /$ fruit. HTP F1 has a short growth cycle; the fruits are pink, firm, fleshy, and juicy with a medium weight of one fruit of 170-250 g. Finally, Inima de Bou cultivar produces big fruits (200-260 g) which have the shape of a heart. All of the cultivars can be cultivated in open-field, greenhouses or tunnels. 


\subsection{Microorganisms}

Rizotech plus ${ }^{\circledR}$ (MsBiotech, Larino, Italy) was used for the inoculation of tomato plants. The product was kindly provided by MsBiotech, Italy. The microorganisms of this commercial product consist of an arbuscular mycorrhizal fungus (Glomus spp.), PGPR (Pseudomonas sp., Bacillus spp., Streptomyces sp.) and a fungus (Trichoderma sp.) in different proportions. The dosage used in our experiments, considering the type of the soil used, was the maximum recommended by the manufacturer, namely $60 \mathrm{~kg} \cdot \mathrm{ha}^{-1}$.

\subsection{Experimental Design}

The experiment was carried out at the experimental station of University of Agricultural Sciences and Veterinary Medicine (UASMV) of Iasi, Romania, in a split plots design, in an individual tunnel of $400 \mathrm{~m}^{2}$. The study was conducted over 3 years, 2017-2019, starting from the middle of April until the middle of October of each year. During the experiment period, the recorded mean temperature was of $17.2^{\circ} \mathrm{C}$ in $2017,18.4{ }^{\circ} \mathrm{C}$ in 2018 and $18.3^{\circ} \mathrm{C}$ in 2019. The sunlight period was of $222 \mathrm{~h}$ in 2017, $244 \mathrm{~h}$ in 2018 and $213 \mathrm{~h}$ in 2019. The registered relative humidity was of $67 \%$ in 2017 , also in 2019 , and of $70 \%$ in 2018. Prior to tomato plants growing, the plots were cultivated with cucumber. The soil used in the experiment was alluvial cambic chernozem with the following characteristics: $62 \%$ sand, $32 \%$ clay, $6 \%$ silt, $26.6 \mathrm{~g} \cdot \mathrm{kg}^{-1}$ organic matter, $28 \mathrm{mg} \cdot \mathrm{kg}^{-1} \mathrm{~N}, 32 \mathrm{mg} \cdot \mathrm{kg}^{-1} \mathrm{P}, 224 \mathrm{mg} \cdot \mathrm{kg}^{-1}$ $\mathrm{K}, 41 \mathrm{mg} \cdot \mathrm{kg}^{-1} \mathrm{CaCO}_{3}, \mathrm{pH} 7.2, \mathrm{EC} 478 \mu \mathrm{S} \cdot \mathrm{cm}^{-1}$. The soil was not subjected to any sterilization or fumigation processes. The experiment was done in triplicate, the surface of one repetition being of $3.6 \mathrm{~m}^{2}$. A number of 12 plants were used for every surface and cultivar. The plants were cultivated in the superficial layer of the soil, so that the roots remained close to the surface. Each cultivar was inoculated with $60 \mathrm{~kg} \cdot \mathrm{ha}^{-1}$ Rizotech plus ${ }^{\circledR} /$ inoculation following a two-treatment scheme: The first treatment was done in the seedling phenophase (14 day after transplanting) and the second treatment at 14 days after planting in tunnel. The inoculation was done close to the roots of tomato plants and was followed by a deep irrigation to enhance the microorganisms' transfer to the roots. Uninoculated plants were used as control. During the experiment, plants were irrigated 26 times (one time/week for $2.5 \mathrm{~h}$ ) with two different amounts of water: $200 \mathrm{~m}^{3} \cdot \mathrm{ha}^{-1}\left(5.200 \mathrm{~m}^{3} /\right.$ vegetation period) and $300 \mathrm{~m}^{3} \cdot \mathrm{ha}^{-1}$ $\left(7.800 \mathrm{~m}^{3} /\right.$ vegetation period). Growing practices (training, pruning and treatments for pests and diseases) were applied for all the plants, according to the techniques described by Stoleru et al., 2014 [3]. During the experiment, when fruits were fully ripened (BBCH 805-808), a minimum of three fruits from each cluster (3-5) were collected for further analyses.

\subsection{Growth Measurements}

The length of the plants and the number of the fruits were measured at the end of the experiment. The yield $\left(\mathrm{kg} \cdot \mathrm{ha}^{-1}\right)$ was calculated by using the following formula: (plants per ha $\times$ fruits per plant $\times$ average fruit weight)/1000.

\subsection{Determination of Lycopene Content}

The lycopene was obtained from ripe tomatoes by solvent extraction as follows: fresh tomatoes were first homogenized in a blender until a puree was obtained. A sample of $0.6 \mathrm{~g}$ of the mixture was added in a vial containing $5 \mathrm{~mL}$ of $0.05 \%(w / v)$ butylated hydroxytoluene (BHT) in acetone, $5 \mathrm{~mL}$ of $95 \%$ ethanol and $10 \mathrm{~mL}$ of hexane. The samples were stirred on a magnetic stirring plate for 15 minutes on ice. After stirring, $3 \mathrm{~mL}$ of deionized water were added in every vial and the samples were shaken for an additional $5 \mathrm{~min}$ on ice. The vials were left at room temperature for $5 \mathrm{~min}$ for the phase separation. The absorbance of the upper layer of hexane was measured at $472 \mathrm{~nm}$ by using hexane as blank [13]. The total lycopene content was calculated by using the following formula: lycopene $\left(\mathrm{mg} \cdot 100 \mathrm{~g}^{-1}\right)=$ $(\mathrm{E} / 3.45) \times(20 / w)$; where $\mathrm{E}=$ extinction coefficient; $w=$ weight $(\mathrm{g})$ [14] . 


\subsection{DPPH Radical-Scavenging Activity}

The antioxidant activity was evaluated by Trolox equivalent antioxidant capacity method (TEAC) assay. Equal volumes of extract or trolox standard and methanolic solution of DPPH (0.1 mM) were mixed and incubated for $30 \mathrm{~min}$ at room temperature, in the dark. After incubation, the absorbance was recorded at $517 \mathrm{~nm}$. The results were expressed as mmol equivalents of trolox (an analog of vitamin E) per $100 \mathrm{~g}$ of fresh weight (FW) $[15,16]$.

\subsection{Determination of Total Phenol Content}

The total phenol content was assessed by using the Folin-Ciocalteu method as follows: $100 \mu \mathrm{L}$ of extract was mixed with $3 \mathrm{~mL}$ distilled water and $100 \mu \mathrm{L}$ Folin-Ciocalteu reagent. The resulting solution was left to rest for $3 \mathrm{~min}$. After that, to each flask, $300 \mu \mathrm{L}$ of $20 \%$ sodium carbonate $(w / v)$ was added. Gallic acid was used as the standard $\left(0-30 \mu \mathrm{g} \cdot \mathrm{mL}^{-1}\right)$. The absorbance of each solution was measured after $2 \mathrm{~h}$ at $760 \mathrm{~nm}$, expressing the results as $\mathrm{mg}$ gallic acid per $100 \mathrm{~g}$ of fresh weight [17].

\subsection{Statistical Analysis}

Experimental results are expressed as means \pm SD. The data were statistically evaluated by two-ways ANOVA with replication. Tukey's test was performed in order to estimate the significant difference between the treatment means and among the cultivars. Differences between groups were considered significant when $p<0.05$.

\section{Results and Discussion}

\subsection{The Effect of Microorganisms' Inoculation and Two Water Treatments on the Length of Tomato Plants}

The results showed that the length of the plants was influenced by the presence of microorganisms from Rizotech Plus ${ }^{\circledR}$ product only in the case of HTP F1cultivar watered with $300 \mathrm{~m}^{3}$, when significant differences were registered between the inoculated and uninoculated plants (Figure 1). For the rest of the cultivars, the presence of microorganisms influenced the length of the plants but not in a significant way. For instance, the length of the plants of Siriana F1 tomato cultivar inoculated with microorganisms is not significant for both irrigation norms (Figure 1). In general, AMF, PGPR or fungi are known for their ability to promote the growth and development of the plants [18-24]. Previous studies have demonstrated that the presence of AMF and PGPR in the rhizosphere stimulate the growth in the length of various plants as: stevia [20], corn [18], habanero chilli [25], cucumber [26], sesame [27], winter wheat [28], or rice [29] mostly due to a better uptake of nutrients by the plant roots. 


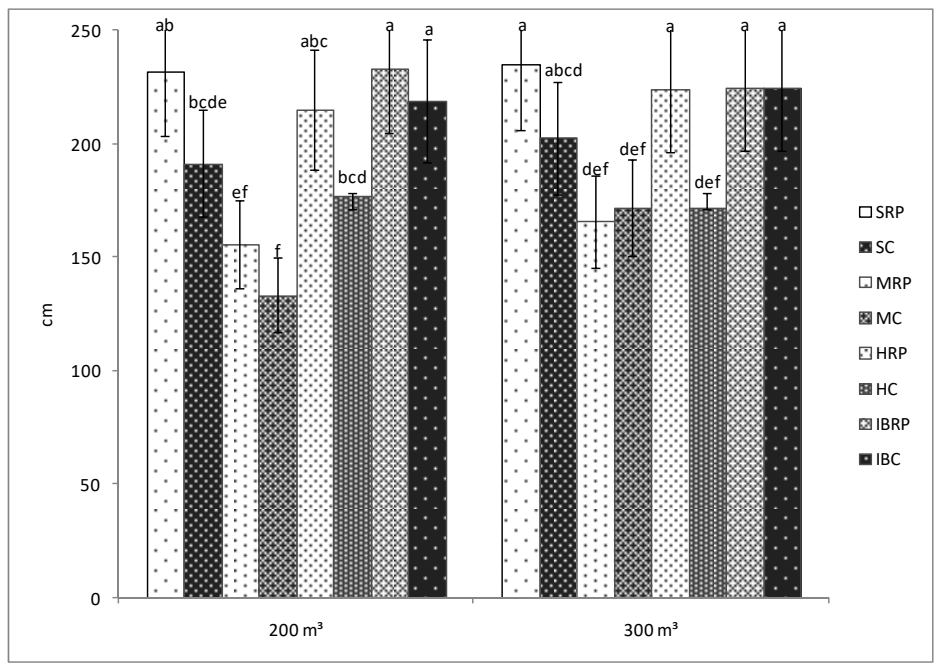

Figure 1. Length of the plants of four tomato cultivars (Siriana F1-S, Minaret F1-M, HTP F1-H, and Inima de Bou- $\mathrm{IB}$ ) in the presence (RP) and absence $(\mathrm{C})$ of Rizotech plus ${ }^{\circledR}$ and two water treatments $\left(200 \mathrm{~m}^{3}\right.$ and $300 \mathrm{~m}^{3}$ water/hectare). Different letters mean significant differences between the treatments, according to Tukey post hoc test $(p<0.05)$.

No significant differences were observed between the length of the inoculated plants when they were irrigated with $200 \mathrm{~m}^{3}$ or $300 \mathrm{~m}^{3}$ of water/hectare (Figure 1). This suggests the fact that Siriana F1, Minaret F1, HTP F1, and Inima de Bou tomato cultivars, in the case of microorganisms' fertilization, can be watered with only $200 \mathrm{~m}^{3} \cdot \mathrm{ha}^{-1}$ to get almost the same length of plants as in the case of $300 \mathrm{~m}^{3} \cdot \mathrm{ha}^{-1}$. In the agricultural practice, water consumption is a very important issue. According to $\mathrm{FAO}$, agriculture is the major water consumer worldwide, accounting on average for $70 \%$ of the total existing freshwater [30]. Use of decreased amounts of water for irrigation represents a sustainable method of water use in agriculture and is also a cost-saving strategy for farmers. Therefore, in the case of the length of the four tomato cultivars, this strategy can be applied.

However, significant differences were noticed between inoculated cultivars in both of the water treatments. Thus, the length of the plants of Siriana F1, HTP F1 and Inima de Bou cultivars was significant bigger than that of the plants of Minaret F1 cultivar, irrespective of the amount of water applied. These differences can be attributed to the fact that Minaret F1cultivar has a semi-determinate growth as compared to the other three cultivars used in the experiments which can grow in an indeterminate manner.

\subsection{The Effect of Microorganisms' Inoculation and Two Water Treatments on the Number of Fruits and Yield of Tomato Plants}

The presence of the microorganisms was of a significant importance only for the tomato plants belonging to Minaret F1 cultivar for which the number of fruits was significantly bigger as compared with the number of the fruits of uninoculated plants, regardless of the amount of water used in the experiment (Figure 2). For the rest of the cultivars, no significant differences were seen between the number of the fruits of inoculated and uninoculated plants, even though for most of the inoculated plants the registered number of fruits was bigger than that of the uninoculated tomato plants. Positive effects of the AMF-bacteria inoculation on the number of fruits have also been observed by Todeschini et al., 2018 [31] in strawberries or by Bona et al., 2017 [32] in tomatoes. 


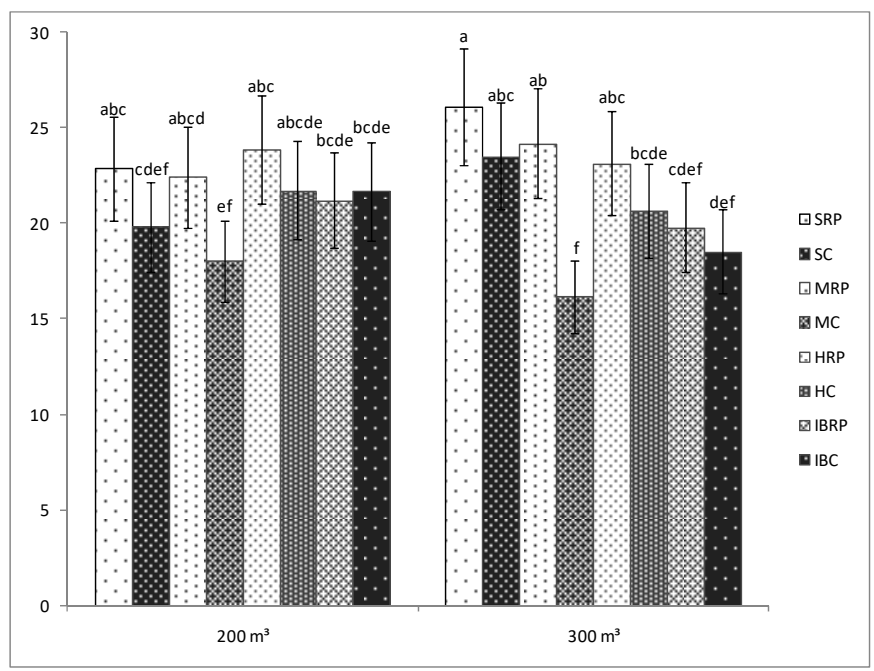

Figure 2. Number of fruits of four tomato cultivars (Siriana F1-S, Minaret F1-M, HTP F1-H, and Inima de Bou-IB) in the presence (RP) and absence $(C)$ of Rizotech plus ${ }^{\circledR}$ and two water treatments $\left(200 \mathrm{~m}^{3}\right.$ and $300 \mathrm{~m}^{3}$ water/hectare). Different letters mean significant differences between the treatments, according to Tukey post hoc test $(p<0.05)$.

Regarding the effects of the two water treatments, it was observed that the fruit number of the inoculated tomato plants cultivars was not influenced by the amount of water used in the experiment. No significant differences were registered between the number of the fruits of the inoculated tomato plants watered with 200 or $300 \mathrm{~m}^{3} \cdot \mathrm{ha}^{-1}$ (Figure 2). Therefore, Siriana F1, Minaret F1, HTP F1, and Inima de Bou tomato cultivars in the condition of fertilization with Rizotech plus ${ }^{\circledR}$, can be watered with only $200 \mathrm{~m}^{3} \cdot \mathrm{ha}^{-1}$ to obtain the same number of fruits as in the case of a $300 \mathrm{~m}^{3} \cdot \mathrm{ha}^{-1}$ water regime.

As in the case of the length of plants and the number of fruits, the yield was not influenced by the amount of water used for irrigation. Therefore, the yield for the inoculated tomato plants watered with $200 \mathrm{~m}^{3} \cdot \mathrm{ha}^{-1}$ was not significantly different than that of the tomato plants irrigated with $300 \mathrm{~m}^{3} \cdot \mathrm{ha}^{-1}$ of water, regardless of the cultivar used in the experiment (Figure 3). However, significant differences were registered between the inoculated and uninoculated plants on both of the water treatments. Thus, the yield of the plants inoculated with Rizotech plus ${ }^{\circledR}$, irrigated with 200 or $300 \mathrm{~m}^{3} \cdot \mathrm{ha}^{-1}$ of water/application belonging to Siriana F1, Minaret F1 and HTP F1 cultivar was significantly bigger than that of the corresponding uninoculated plants. No differences were noticed between the inoculated and uninoculated Inima de Bou tomato cultivar irrespective of the amount of water used for irrigation (Figure 3). 


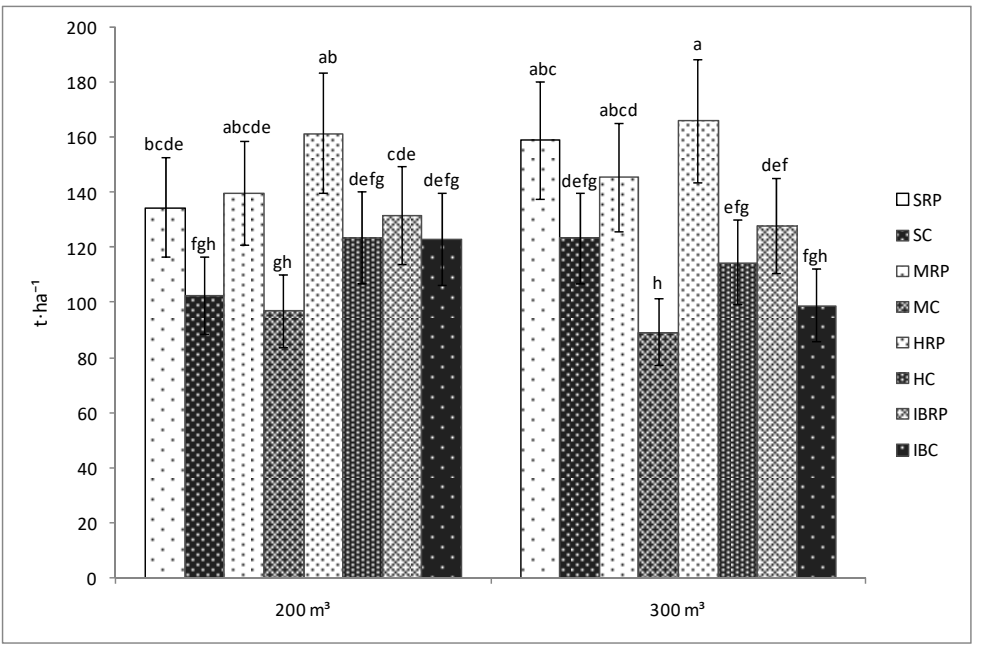

Figure 3. Yield of four tomato cultivars (Siriana F1-S, Minaret F1-M, HTP F1-H, and Inima de Bou-IB) in the presence (RP) and absence (C) of Rizotech plus ${ }^{\circledR}$ and two water treatments $\left(200 \mathrm{~m}^{3}\right.$ and $300 \mathrm{~m}^{3}$ water/hectare). Different letters mean significant differences between the treatments, according to Tukey post hoc test $(p<0.05)$.

Moreover, it was observed that between the inoculated cultivars, the yield of the inoculated tomato plants belonging to HTP F1 cultivar was significantly bigger $\left(161.7 \mathrm{t} \cdot \mathrm{ha}^{-1}\right.$, respectively $\left.166.25 \mathrm{t} \cdot \mathrm{ha}^{-1}\right)$ as compared with that of Inima de Bou cultivar $\left(132.7 \mathrm{t}^{-h^{-1}}\right.$, respectively $\left.128.11 \mathrm{t} \cdot \mathrm{ha}^{-1}\right)$ at both of the water amounts (200 and $300 \mathrm{~m}^{3} \cdot \mathrm{ha}^{-1}$ ) used in the experiments. No significant differences were noticed between the other inoculated cultivars (Figure 3).

Therefore, the inoculation of the four tomato cultivars used in the experiments with AMF-bacteria-fungus had positively influenced the shoot length, the number of the fruits and the yield of the plants. While increases in shoot length are a very well-known consequence of microorganisms' action, their effects on the number of fruits and yield is less studied. In greenhouse experiments, the yield of the tomato plants seems to be enhanced by the microorganisms' inoculation as demonstrated by Hart et al., 2015 [33], by Salvioli et al., 2012 [34] or by Conversa et al., 2013 [35]. Regarding the number of fruits and the yield obtained in the protected area or field due to biofertilizer application, the results largely vary along with the plant species and cultivars, the microorganisms used for inoculation, the interactions between the rhizospheric organisms, the physical and chemical conditions of the soil, as well as with the environmental factors like temperatures or precipitations [36]. In our study, the microorganisms from Rizotech plus ${ }^{\circledR}$ product inoculated to Siriana F1, Minaret F1 and HTP F1 tomato cultivars grown in tunnel, significantly increased the yield of the plants as compared to the uninoculated tomato plants, irrespective of the water amount used in the experiments, demonstrating the importance of their presence on the plant's root.

\subsection{The Effect of the Microorganisms' Inoculation and the Two Water Treatments on the Lycopene, Polyphenols Content and Antioxidant Activity of Tomatoes}

The data showed that the efficiency of microorganism's treatments is dependent on the amount of water used and on the tomato cultivar when it comes to the tomato fruit's quality such as lycopene, polyphenols and antioxidant activity (Table 1). 
Table 1. Effects of the microorganisms' inoculation and the two water treatments on the antioxidant activity, polyphenol and lycopene content of tomatoes.

\begin{tabular}{|c|c|c|c|}
\hline Treatment & $\begin{array}{c}\text { Lycopene } \\
\left(\mathrm{mg} \cdot 100 \mathrm{~g}^{-1} \mathrm{FW}\right) 472 \mathrm{~nm}\end{array}$ & $\begin{array}{c}\text { Polyphenol } \\
\left(\mathrm{mg} \cdot 100 \mathrm{~g}^{-1} \mathrm{FW}\right)\end{array}$ & $\begin{array}{c}\text { Antioxidant Activity } \\
\left(\mathrm{mmol} \text { Trol } \cdot 100 \mathrm{~g}^{-1} \mathrm{FW}\right)\end{array}$ \\
\hline SRP 200 & $11.16 \pm 0.7 \mathrm{de}$ & $2283.38 \pm 285.6$ bcde & $81.39 \pm 4.5$ cdef \\
\hline SRP 300 & $11.63 \pm 0.7 \mathrm{bcd}$ & $2322.216 \pm 410.8 \mathrm{bcd}$ & $85.34 \pm 4.5 \mathrm{~cd}$ \\
\hline SC 200 & $9.01 \pm 0.1 \mathrm{~h}$ & $2165.28 \pm 280.2$ bcde & $76.63 \pm 5.5 \mathrm{efg}$ \\
\hline SC 300 & $9.81 \pm 0.2 \mathrm{~g}$ & $2228.186 \pm 362.5$ bcde & $82.44 \pm 1.9 \mathrm{cdef}$ \\
\hline MRP 200 & $11.03 \pm 0.1 \mathrm{def}$ & $2805.128 \pm 286.8 \mathrm{a}$ & $87.563 \pm 5.6 \mathrm{bc}$ \\
\hline MRP 300 & $11.31 \pm 0.3 \mathrm{de}$ & $2820.385 \pm 412.9 \mathrm{a}$ & $94.887 \pm 2.8 \mathrm{a}$ \\
\hline MC 200 & $10.39 \pm 0.5 \mathrm{fg}$ & $1863.402 \pm 141.2 \mathrm{de}$ & $83.85 \pm 3.8 \mathrm{cde}$ \\
\hline MC 300 & $10.89 \pm 0.1$ ef & $1882.277 \pm 96.4 \mathrm{de}$ & $85.93 \pm 4.6 \mathrm{~cd}$ \\
\hline HRP 200 & $12.09 \pm 0.5 b$ & $2184.21 \pm 157.4$ bcde & $94.05 \pm 4.1 \mathrm{ab}$ \\
\hline HRP 300 & $13.02 \pm 0.3 \mathrm{a}$ & $2382.274 \pm 449.2 \mathrm{abc}$ & $93.97 \pm 4.9 \mathrm{ab}$ \\
\hline HC 200 & $11.09 \pm 0.3 \mathrm{de}$ & $1808.253 \pm 88.2 \mathrm{e}$ & $70.39 \pm 2.5 \mathrm{gh}$ \\
\hline HC 300 & $12 \pm 0.4 b c$ & $1988.377 \pm 156.7$ bcde & $65.12 \pm 4.8 \mathrm{~h}$ \\
\hline IBRP 200 & $11.5 \pm 0.2$ bcde & $2423.26 \pm 306.2 \mathrm{ab}$ & $86.96 \pm 3.7 \mathrm{bc}$ \\
\hline IBRP 300 & $13.12 \pm 0.2 \mathrm{a}$ & $2425.239 \pm 352 a b$ & $83.92 \pm 3.5$ cde \\
\hline IBC 200 & $11.28 \pm 0.3 \mathrm{de}$ & $1926.223 \pm 104.9$ cde & $78.71 \pm 7.1 \mathrm{def}$ \\
\hline IBC 300 & $11.35 \pm 0.6$ cde & $1942.296 \pm 108.9$ cde & $75.94 \pm 2.9 \mathrm{fg}$ \\
\hline
\end{tabular}

Different letters mean significant differences between the treatments, according to Tukey posthoc test $(p<0.05)$. $\mathrm{S}=$ Siriana F1; M = Minaret F1; H = HTP F1; IB = Inima de Bou; RP= Rizotech plus ${ }^{\circledR} ; \mathrm{C}=$ control; $200=200 \mathrm{~m}^{3}$ water $\cdot \mathrm{ha}^{-1} ; 300=300 \mathrm{~m}^{3}$ water.ha ${ }^{-1}$.

Lycopene represents $60-74 \%$ of the carotenoids present in tomatoes, being an essential nutrient for the human diet due to its high antioxidant capacity [37,38]. Studies have reported that due to the protective effects of the carotenoids, tomato consumption decreases the risk of cardiovascular disease, atherosclerosis, and cancer, as well as regulating the immune system [39-41]. The lycopene content of tomato fruits can vary with the cultivar, the environmental factors or the presence of microorganisms [42].

In the samples measured in this study, the lycopene content of the tomato fruits belonging to Siriana F1 and HTP F1 cultivars inoculated with Rizotech plus ${ }^{\circledR}$, regardless of the water used for irrigation, also for Inima de Bou cultivar watered with $300 \mathrm{~m}^{3}$ water/ha, was significantly higher (Siriana F1-11.16, $11.63 \mathrm{mg} \cdot 100 \mathrm{~g}^{-1} \mathrm{FW}$; HTP F1—12.09, $13.02 \mathrm{mg} \cdot 100 \mathrm{~g}^{-1} \mathrm{FW}$; Inima de Bou—13.12 mg $100 \mathrm{~g}^{-1}$ FW) than that of the tomato fruits from the corresponding uninoculated plants $\left(9.01,9.81 \mathrm{mg} \cdot 100 \mathrm{~g}^{-1}\right.$ FW; $11.09,12 \mathrm{mg} \cdot 100 \mathrm{~g}^{-1} \mathrm{FW}$; and $11.35 \mathrm{mg} \cdot 100 \mathrm{~g}^{-1} \mathrm{FW}$ respectively), under the same water regime (Table 1). We can presume that the presence of the microorganisms contributed to the increase of the lycopene content of the tomatoes, probably due to the nutrient status improvement of the plants. Studies have shown that increases in potassium or phosphorus content enhance the lycopene content in tomato fruits [43]. Taking into account that Rizotech plus ${ }^{\circledR}$ contains microorganisms that are known for promoting the growth and development of plants, this hypothesis can be taken into consideration. No significant differences in lycopene were registered between the tomatoes of Minaret F1 (at 200 or $300 \mathrm{~m}^{3}$ water/ha) or Inima de Bou (at $200 \mathrm{~m}^{3}$ water/ha) inoculated cultivars and the tomatoes of the corresponding uninoculated plants.

Regarding the influence of the amount of water applied on the lycopene content of the tomato fruits, no significant differences were seen between the inoculated plants of Siriana F1 or Minaret F1 cultivars irrigated with 200 or $300 \mathrm{~m}^{3}$ water.ha ${ }^{-1}$ (Table 1). These findings are in accordance with the results regarding the length of the plants, the number of fruits, and the yield when no differences were seen between the tomato plants watered with the two water treatments. Anyway, the lycopene content of the tomato fruits of HTP F1 and Inima de Bou inoculated cultivars was significantly higher when water was used in an amount of $300 \mathrm{~m}^{3} \cdot \mathrm{ha}^{-1}$ as compared with $200 \mathrm{~m}^{3} \cdot \mathrm{ha}^{-1}$ (Table 1). According to Grolier et al., 1999 and Atkinson et al., 2011, water stress can reduce the lycopene content in tomato [44,45]. Therefore, in our study, probably, the irrigation of HTP F1 and Inima de Bou tomato cultivar with $200 \mathrm{~m}^{3} \cdot \mathrm{ha}^{-1}$ represented a water stress condition for the lycopene production. 
However, at $200 \mathrm{~m}^{3}$ water $\cdot \mathrm{ha}^{-1}$, the best lycopene content was recorded for the tomato fruits of HTP F1 cultivar $\left(13.02 \mathrm{mg} \cdot 100 \mathrm{~g}^{-1} \mathrm{FW}\right)$, while at $300 \mathrm{~m}^{3} \cdot \mathrm{ha}^{-1}$ for Inima de Bou cultivar $(13.12 \mathrm{mg} \cdot 100 \mathrm{~g}-1$ FW). The lowest content regardless of the water amount (200 or $\left.300 \mathrm{~m}^{3} \cdot \mathrm{ha}^{-1}\right)$ used was registered for Minaret F1cultivar (11.03 mg.100 $\mathrm{g}^{-1} \mathrm{FW}$ and $11.31 \mathrm{mg} \cdot 100 \mathrm{~g}^{-1} \mathrm{FW}$ respectively). Considering the results of the lycopene content, we can conclude that the efficiency of Rizotech plus ${ }^{\circledR}$ product on this parameter varied along with the tomato cultivar used in the experiment and the water amount applied.

Polyphenols are known for their antioxidant capacity, being very important in the human diet for lowering the risk of cardiovascular disease or cancer or for increasing the resistance of low-density lipoprotein (LDL). As in the case of lycopene, the polyphenol content in plants depends on the cultivation and harvesting conditions such as growing conditions, degree of ripeness and plant variety $[46,47]$.

The presence of the microorganisms significantly affected the polyphenols content of the tomatoes from Minaret F1 and Inima de Bou cultivars, at both 200 and $300 \mathrm{~m}^{3} \cdot \mathrm{ha}^{-1}$, when a significant higher value was recorded as compared to the uninoculated plants, but had no effect on Siriana and HTP F1 cultivars, regardless of the amount of water used, when no differences between the inoculated and the uninoculated plants were seen (Table 1). As in the case of the length of the plants, the number of fruits and the yield, no differences in polyphenol content could be seen between the two water treatments used in the experiments for the plants inoculated with Rizotech plus ${ }^{\circledR}$. Therefore, for the cultivars inoculated with microorganisms, by using a lower amount of water for irrigation $\left(200 \mathrm{~m}^{3} \cdot \mathrm{ha}^{-1}\right)$, it can get the same polyphenol content as in the case of a higher amount $\left(300 \mathrm{~m}^{3} \cdot \mathrm{ha}^{-1}\right)$. The highest content of polyphenols at a water regime of $200 \mathrm{~m}^{3} \cdot \mathrm{ha}^{-1}$ was registered for Minaret F1 and Inima de Bou cultivars (2805.128 and $2423.26 \mathrm{mg} \cdot 100 \mathrm{~g}^{-1} \mathrm{FW}$ ), between which no significant differences were observed. At this water amount, significant differences were recorded only between the polyphenol content of the Minaret F1cultivar and Siriana F1 (2283.38 mg $\left.100 \mathrm{~g}^{-1} \mathrm{FW}\right)$, as well as HTP F1 (2184.21 mg.100 g $\left.{ }^{-1} \mathrm{FW}\right)$ cultivars (Table 1). At $300 \mathrm{~m}^{3} \cdot \mathrm{ha}^{-1}$, the highest content was registered for the same Minaret F1 and Inima de Bou cultivars, but also for HTP F1 cultivar (2820.385, 2425.239 and $2382 \mathrm{mg} \cdot 100 \mathrm{~g}^{-1} \mathrm{FW}$ respectively). Significant differences were seen only between Minaret F1 and Siriana F1 (2322.216 mg.100 g ${ }^{-1}$ FW) cultivars. No differences in the polyphenol content were registered for the rest of the cultivars.

Finally, the antioxidant activity of HTP F1 and Inima de Bou cultivars was significantly influenced by the presence of the microorganisms regardless of the water amount used in experiment. For these cultivars, the antioxidant activity was significantly higher as compared to the uninoculated plants (Table 1). Similarly, Ordookhani and Zare, 2011, reported a higher level of antioxidant activity in the tomato fruits of the plants inoculated with a combination of PGPR and AMF than in the case when no inoculation was considered [48].

For Minaret F1 cultivar, the presence of the microorganisms resulted in a higher antioxidant activity only in the case of the plants irrigated with $300 \mathrm{~m}^{3} \cdot \mathrm{ha}^{-1}\left(94.887 \mathrm{mmol} \mathrm{Trol} \cdot 100 \mathrm{~g}^{-1} \mathrm{FW}-\right.$ inoculated plants vs. $85.93 \mathrm{mmol}$ Trol $100 \mathrm{~g}^{-1} \mathrm{FW}$-uninoculated plants), but no differences were recorded between the inoculated and uninoculated plants watered with $200 \mathrm{~m}^{3} \cdot \mathrm{ha}^{-1}$ or between the Siriana F1 cultivar plants irrespective of the water treatment applied. The antioxidant activity was not influenced by the water amount used in the experiments, for three of the cultivars analyzed. Therefore, no differences in the antioxidant activity were seen between the inoculated tomato plants of Siriana F1, HTP F1 and Inima de bou cultivars irrigated with either 200 or $300 \mathrm{~m}^{3} \cdot \mathrm{ha}^{-1}$. Only in the case of the inoculated Minaret F1 cultivar, the antioxidant activity of the plants watered with $300 \mathrm{~m}^{3} \cdot \mathrm{ha}^{-1}\left(94.887 \mathrm{mmol}\right.$ Trol $\left.\cdot 100 \mathrm{~g}^{-1} \mathrm{FW}\right)$ was significantly higher than that of the plants irrigated with $200 \mathrm{~m}^{3} \cdot \mathrm{ha}^{-1}\left(87.563 \mathrm{mmolTrol} \cdot 100 \mathrm{~g}^{-1} \mathrm{FW}\right)$. The best antioxidant activity in the case of $200 \mathrm{~m}^{3} \cdot \mathrm{ha}^{-1}$ irrigation was registered for the inoculated plants of HTP F1 cultivar (94.05 mmol Trol·100 g $\left.{ }^{-1} \mathrm{FW}\right)$, followed by Minaret F1 (87.563 mmol Trol $\left.100 \mathrm{~g}^{-1} \mathrm{FW}\right)$, Inima de Bou (86.96 mmol Trol $\left.\cdot 100 \mathrm{~g}^{-1} \mathrm{FW}\right)$, and Siriana F1 (81.39 mmol Trol $100 \mathrm{~g}^{-1} \mathrm{FW}$ ) cultivar. Significant differences were seen only between the antioxidant activity of inoculated Siriana F1 and HTP F1 cultivar. When the water treatment was $300 \mathrm{~m}^{3} \cdot \mathrm{ha}^{-1}$, the best antioxidant activity was recorded for Minaret F1 (94.887 mmol Trol $\left.\cdot 100 \mathrm{~g}^{-1} \mathrm{FW}\right)$ 
and HTP F1 (93.97 mmol Trol $\left.100 \mathrm{~g}^{-1} \mathrm{FW}\right)$ followed by Siriana F1 (85.34 mmol Trol $\left.100 \mathrm{~g}^{-1} \mathrm{FW}\right)$ and Inima de Bou ( $83.92 \mathrm{mmol}$ Trol $100 \mathrm{~g}^{-1} \mathrm{FW}$ ) inoculated cultivars (Table 1).

\section{Conclusions}

This study shows that the microorganisms from Rizotech plus ${ }^{\circledR}$ product had a positive effect on the growth of tomato plants belonging to Siriana F1, Minaret F1, HTP F1, and Inima de Bou cultivars, influencing the length of the plants, the number of fruits, and the yield. Moreover, the presence of the microorganisms enhanced the tomato fruits quality such as lycopene, polyphenol and the antioxidant activity which are very important in the human diet. The efficiency of Rizotech plus ${ }^{\circledR}$ application is however dependent on the cultivar and the amount of water used. Anyway, the results definitely demonstrate that the Rizotech plus ${ }^{\circledR}$ inoculation significantly increased the yield of Siriana F1, Minaret F1 and HTP F1 cultivars as compared to the uninoculated plants, regardless of the water amount used in the experiment. Moreover, the results strongly suggest that for the irrigation of Siriana F1, Minaret F1, HTP F1, and Inima de Bou cultivars, inoculated with Rizotech plus ${ }^{\circledR}$, a lower amount of water $\left(200 \mathrm{~m}^{3} \cdot \mathrm{ha}^{-1}\right)$ can be used to get the same length of plants, number of fruits and yield as in the case of a higher amount of water $\left(300 \mathrm{~m}^{3} \cdot \mathrm{ha}^{-1}\right)$. In the case of lycopene, polyphenols and antioxidant activity, this situation is cultivar- and water-dependent. The results obtained in this study give new information about the functionality and performance of the microorganisms from Rizotech plus ${ }^{\circledR}$ product when applied to different tomato cultivars, in the condition of two different water regimes, contributing to a better characterization of it and maybe to a more efficient use in agriculture to get optimum results. Further studies should be conducted to see how other important parameters such as the soil type affects the efficiency of this microorganisms-based product.

Author Contributions: Conceptualization, C.-S.I. and V.S.; methodology, C.-S.I. and V.S.; data analysis, G.M.; investigation, C.-S.I.; resources, V.M.S.; data curation, G.M. and V.S.; writing-original draft preparation, G.M. and V.S.; writing-review and editing, G.M., V.S. and R.-M.H.; supervision, V.S.

Funding: This research received no external funding.

Acknowledgments: We would like to express our appreciation to Butnariu Monica considering her helpful contributions in biochemical analysis and MsBiotech for providing Rizotech plus ${ }^{\circledR}$ product.

Conflicts of Interest: The authors declare no conflict of interest.

\section{References}

1. Christensen, J.H.; Hewitson, B.; Busuioc, A.; Chen, A.; Gao, X.; Held, I.; Jones, R.; Kolli, R.K.; Kwon, W.T.; Laprise, R. IPCC, 2007: Climate Change 2007: The Physical Science Basis; Contribution of Working Group I to the Fourth Assessment Report of the Intergovernmental Panel on Climate Change; Solomon, S., Qin, D., Manning, M., Chen, Z., Marquis, M., Averyt, K.B., Tignor, M., Miller, H.L., Eds.; Cambridge University Press: Cambridge, UK; New York, NY, USA, 2007; pp. 848-940.

2. Golldack, D.; Li, C.; Mohan, H.; Probst, N. Tolerance to drought and salt stress in plants: Unraveling the signaling networks. Front. Plant Sci. 2014, 5, 151. [CrossRef] [PubMed]

3. Stoleru, V.; Munteanu, N.; Sellitto, V.M. New Approach of Organic Vegetable Systems; AracneeEditrice: Rome, Italy, 2014.

4. Stefan, M.; Munteanu, N.; Stoleru, V.; Mihasan, M.; Hritcu, L. Seed inoculation with plant growth promoting rhizobacteria enhances photosynthesis and yield of runner bean (Phaseolus coccineus L.). Sci. Hortic. 2013, 151, $22-29$. [CrossRef]

5. Raklami, A.; Bechtaoui, N.; Tahiri, A.-I.; Anli, M.; Meddich, A.; Oufdou, K. Use of rhizobacteria and mycorrhizae consortium in the open field as a strategy for improving crop nutrition, productivity and soil fertility. Front. Microbiol. 2019, 10, 1106. [CrossRef] [PubMed]

6. Mihalache, G.; Zamfirache, M.M.; Stefan, M. Root associated bacteria-Friends or enemies? A review. Mem. Sci. Sect. Rom. Acad. 2015, 38, 27-54.

7. Stefan, M.; Munteanu, N.; Stoleru, V.; Mihasan, M. Effects of inoculation with plant growth promoting rhizobacteria on photosynthesis, antioxidant status and yield of runner bean. Rom. Biotechnol. Lett. 2013, 18, 8132-8143. 
8. Lernaoud, J.; Potts, J.; Sampson, G.; Schlatter, B.; Huppe, G.; Voora, V.; Willer, H.; Wozniak, J. The state of sustainable markets: Statistics and emerging trends. In The World of Organic Agriculture, Statistics and Emerging Trends; Willer, H., Lernoud, J., Eds.; Research Insitute of Organic Agriculture (FiBL), Frick, and IFOAM-Organics International: Bonn, Germany, 2019; pp. 130-137.

9. Tan, H.-L.; Thomas-Ahner, J.M.; Grainger, E.M.; Wan, L.; Francis, D.M.; Schwartz, S.J.; Erdman, J.W.; Clinton, S.K. Tomato-based food products for prostate cancer prevention: What have we learned? Cancer Metastasis Rev. 2010, 29, 553-568. [CrossRef] [PubMed]

10. Hariprasad, P.; Venkateswaran, G.; Niranjana, S.R. Diversity of cultivable rhizobacteria across tomato growing regions of Karnataka. Biol. Control 2014, 72, 9-16. [CrossRef]

11. Krishnamoorthy, R.; Manoharan, M.J.; Kim, K.; Lee, S.; Shagol, C.; Rangasamy, A.; Chung, J.; Islam, M.R.; Sa, T. Synergistic effects of arbuscular mycorrhizal fungi and plant growth promoting rhizobacteria for sustainable agricultural production. Korean Soc. Soil Sci. Fertil. 2011, 44, 637-649.

12. Figueiredo, M.; Seldin, L.; Araujo, F.; Mariano, R. Plant growth promoting rhizobacteria: Fundamentals and applications. In Plant Growth and Health Promoting Bacteria; Maheshwari, D.K., Ed.; Springer: Berlin/Heidelberg, Germany, 2011; Volume 18, pp. 21-43.

13. Butnariu, M.V.; Giuchici, C.V. The use of some nanoemulsions based on aqueous propolis and lycopene extract in the skin's protective mechanisms against UVA radiation. J. Nanobiotechnol. 2011, 9, 3. [CrossRef] [PubMed]

14. Sharma, S.K.; Le Maguer, M. Lycopene in tomatoes and tomato pulp fractions. Ital. J. Food Sci. 1996, 2, $107-113$.

15. Caruso, G.; Stoleru, V.; Munteanu, N.; Sellitto, V.M.; Teliban, G.C.; Burducea, M.; Tenu, I.; Morano, G.; Butnariu, M.V. Quality performances of sweet pepper under farming management. Not. Bot. Horti Agrobot. Cluj-Napoca 2018, 47, 458-464. [CrossRef]

16. Grajeda-Iglesias, C.; Salas, E.; Barouh, N.; Baréa, B.; Panya, A.; Figueroa-Espinoza, M.C. Antioxidant activity of protocatechuates evaluated by DPPH, ORAC, and CAT methods. Food Chem. 2016, 194, 749-757. [CrossRef] [PubMed]

17. Singleton, V.L.; Orthofer, R.; Lamuela-Raventós, R.M. Analysis of total phenols and other oxidation substrates and antioxidants by means of folin-ciocalteu reagent. In Methods in Enzymology; Academic Press: Cambridge, MA, USA, 1999; Volume 299, pp. 152-178.

18. Adesemoye, A.O.; Torbert, H.A.; Kloepper, J.W. Enhanced plant nutrient use efficiency with PGPR and AMF in an integrated nutrient management system. Can. J. Microbiol. 2008, 54, 876-886. [CrossRef] [PubMed]

19. Gamalero, E.; Trotta, A.; Massa, N.; Copetta, A.; Martinotti, M.G.; Berta, G. Impact of two fluorescent pseudomonads and an arbuscularmycorrhizal fungus on tomato plant growth, root architecture and $\mathrm{P}$ acquisition. Mycorrhiza 2004, 14, 185-192. [CrossRef]

20. Vafadar, F.; Amooaghaie, R.; Otroshy, M. Effects of plant-growth-promoting rhizobacteria and arbuscularmycorrhizal fungus on plant growth, stevioside, NPK, and chlorophyll content of Stevia rebaudiana. J. Plant Interact. 2014, 9, 128-136. [CrossRef]

21. Roesti, D.; Gaur, R.; Johri, B.N.; Imfeld, G.; Sharma, S.; Kawaljeet, K.; Aragno, M. Plant growth stage, fertiliser management and bio-inoculation of arbuscularmycorrhizal fungi and plant growth promoting rhizobacteria affect the rhizobacterial community structure in rain-fed wheat fields. Soil Biol. Biochem. 2006, 38, 1111-1120. [CrossRef]

22. Mohamed, I.; Eid, K.E.; Abbas, M.H.H.; Salem, A.A.; Ahmed, N.; Ali, M.; Shah, G.M.; Fang, C. Use of plant growth promoting rhizobacteria (PGPR) and mycorrhizae to improve the growth and nutrient utilization of common bean in a soil infected with white rot fungi. Ecotoxicol. Environ. Saf. 2019, 171, 539-548. [CrossRef]

23. Pathak, D.; Lone, R.; Khan, S.; Koul, K.K. Isolation, screening and molecular characterization of free-living bacteria of potato (Solanum tuberosum L.) and their interplay impact on growth and production of potato plant under mycorrhizal association. Sci. Hortic. 2019, 252, 388-397. [CrossRef]

24. Marulanda-Aguirre, A.; Azcón, R.; Ruiz-Lozano, J.M.; Aroca, R. Differential effects of a Bacillus megaterium strain on Lactuca sativa plant growth depending on the origin of the arbuscularmycorrhizal fungus coinoculated: Physiologic and biochemical traits. J. Plant Growth Regul. 2007, 27, 10. [CrossRef]

25. Constantino, M.; Gomez-Alvarez, R.; Alvarez-Sol, J.D.; Geissen, V.; Huerta, E.; Barba, E. Effect of inoculation with rhizobacteria and arbuscularmycorrhizal fungi on growth and yield of Capsicum chinense Jacquin. J. Agric. Rural Dev. Trop. Subtrop. 2008, 109, 169-180. 
26. Gamalero, E.; Berta, G.; Massa, N.; Glick, B.R.; Lingua, G. Synergistic interactions between the ACC deaminase-producing bacterium Pseudomonas putida UW4 and the AM fungus Gigaspora rosea positively affect cucumber plant growth. Fems Microbiol. Ecol. 2008, 64, 459-467. [CrossRef]

27. Sabannavar, S.J.; Lakshman, H.C. Effect of rock phosphate solubilizatio using mycorrhizal fungi and phosphobacteria on two high yielding varieties of Sesamum indicum L. World J. Agric. Sci. 2009, 5, 470-479.

28. Arthurson, V.; Hjort, K.; Muleta, D.; Jaderlund, L.; Granhall, U. Effects on Glomus mosseae root colonization by Paenibacillus polymyxa and Paenibacillus brasilensis strains as related to soil P-availability in winter wheat. Appl. Environ. Soil Sci. 2011, 2011, 298097. [CrossRef]

29. Ruíz-Sánchez, M.; Armada, E.; Muñoz, Y.; García de Salamone, I.E.; Aroca, R.; Ruíz-Lozano, J.M.; Azcón, R. Azospirillum and arbuscularmycorrhizal colonization enhance rice growth and physiological traits under well-watered and drought conditions. J. Plant Physiol. 2011, 168, 1031-1037. [CrossRef]

30. FAO. Water for Sustainable Food and Agriculture-A Report for the G20 Precidency of Germany; FAO: Rome, Italy, 2017.

31. Todeschini, V.; AitLahmidi, N.; Mazzucco, E.; Marsano, F.; Gosetti, F.; Robotti, E.; Bona, E.; Massa, N.; Bonneau, L.; Marengo, E.; et al. Impact of beneficial microorganisms on strawberry growth, fruit production, nutritional quality, and volatilome. Front. Plant Sci. 2018, 9, 1611. [CrossRef]

32. Bona, E.; Cantamessa, S.; Massa, N.; Manassero, P.; Marsano, F.; Copetta, A.; Lingua, G.; D'Agostino, G.; Gamalero, E.; Berta, G. Arbuscularmycorrhizal fungi and plant growth-promoting pseudomonads improve yield, quality and nutritional value of tomato: A field study. Mycorrhiza 2017, 27, 1-11. [CrossRef]

33. Hart, M.; Ehret, D.L.; Krumbein, A.; Leung, C.; Murch, S.; Turi, C.; Franken, P. Inoculation with arbuscularmycorrhizal fungi improves the nutritional value of tomatoes. Mycorrhiza 2015, 25, 359-376. [CrossRef]

34. Salvioli, A.; Zouari, I.; Chalot, M.; Bonfante, P. The arbuscularmycorrhizal status has an impact on the transcriptome profile and amino acid composition of tomato fruit. BMC Plant Biol. 2012, 12, 44. [CrossRef] [PubMed]

35. Conversa, G.; Lazzizera, C.; Bonasia, A.; Elia, A. Yield and phosphorus uptake of a processing tomato crop grown at different phosphorus levels in a calcareous soil as affected by mycorrhizal inoculation under field conditions. Biol. Fertil. Soils 2013, 49, 691-703. [CrossRef]

36. Fuentes-Ramirez, L.E.; Caballero-Mellado, J. Bacterial biofertilizers. In PGPR: Biocontrol and Biofertilization; Siddiqui, Z.A., Ed.; Springer: Dordrecht, The Netherlands, 2006; pp. 143-172.

37. Martínez-Valverde, I.; Periago, M.J.; Provan, G.; Chesson, A. Phenolic compounds, lycopene and antioxidant activity in commercial varieties of tomato (Lycopersicum esculentum). J. Sci. Food Agric. 2002, 82, 323-330. [CrossRef]

38. Agarwal, S.; Rao, A.V. Tomato lycopene and its role in human health and chronic diseases. CMAJ 2000, 163, 739-744.

39. Brandt, S.; Pék, Z.; Barna, É.; Lugasi, A.; Helyes, L. Lycopene content and colour of ripening tomatoes as affected by environmental conditions. J. Sci. Food Agric. 2006, 86, 568-572. [CrossRef]

40. Xu, F.; Yuan, Q.-P.; Zhu, Y. Improved production of lycopene and $\beta$-carotene by Blakeslea trispora with oxygen-vectors. Process Biochem. 2007, 42, 289-293. [CrossRef]

41. Szabo, K.; Diaconeasa, Z.; Cătoi, A.F.; Vodnar, D.C. Screening of ten tomato varieties processing waste for bioactive components and their related antioxidant and antimicrobial activities. Antioxidants 2019, 8, 292. [CrossRef]

42. Ordookhani, K.; Khavazi, K.; Moezzi, A.; Rejali, F. Influence of PGPR and AMF on the antioxidant activity, lycopene and potassium contents in tomato. Afr. J. Agric. Res. 2010, 5, 1108-1116.

43. Nzanza, B.; Marais, D.; Soundy, P. Yield and nutrient content of tomato (Solanum lycopersicum L.) as influenced by Trichoderma harzianum and Glomus mosseae inoculation. Sci. Hortic. 2012, 144, 55-59. [CrossRef]

44. Grolier, P.; Bartholin, G.; Caris-Veyrat, C.; Dadomo, M.; Dumas, Y.; Meddens, F.; Sandei, L.; Schuch, W. Antioxidants in tomato fruit. In Role and Control of Antioxidants in the Tomato Processing Industry; European Commission Concerted Action, FAIR. CT 97-3233, Seminar in Parma; European Commission: Brussels, Belgium, 1999; pp. 9-12.

45. Atkinson, N.J.; Dew, T.P.; Orfila, C.; Urwin, P.E. Influence of combined biotic and abiotic stress on nutritional quality parameters in tomato (Solanum lycopersicum). J. Agric. Food Chem. 2011, 59, 9673-9682. [CrossRef] [PubMed] 
46. Vallverdú-Queralt, A.; Medina-Remón, A.; Casals-Ribes, I.; Lamuela-Raventos, R.M. Is there any difference between the phenolic content of organic and conventional tomato juices? Food Chem. 2012, 130, 222-227. [CrossRef]

47. El-Marzouq, M. Analysis and antioxidant activity of phenolic compounds in olive and fig leaves juice. Banat. J. Biotechnol. 2013, 4, 47-53.

48. Ordookhani, K.; Zare, M. Effects of Pseudomonas, Azotobacter and arbuscularmycorrhiza fungi on lycopene, antioxidant activity and total soluble solid in tomato (Lycopersicon esculentulm F1 hybrid, Delba). Adv. Environ. Biol. 2011, 5, 1290-1294.

(C) 2019 by the authors. Licensee MDPI, Basel, Switzerland. This article is an open access article distributed under the terms and conditions of the Creative Commons Attribution (CC BY) license (http://creativecommons.org/licenses/by/4.0/). 